\title{
Critical Thinking Disposition: The Effects of Infusion Approach in Engineering Drawing
}

\author{
Norazlinda Mohd Darby ${ }^{1} \&$ Abdullah Mat Rashid ${ }^{2}$ \\ ${ }^{1}$ Kementerian Pendidikan Malaysia, Malaysia \\ ${ }^{2}$ Universiti Putra Malaysia, Malaysia \\ Correspondence: Norazlinda Mohd Darby, Kementerian Pendidikan Malaysia, Malaysia. E-mail: \\ norazlinda_7@yahoo.com \\ Received: April 9, 2017 \\ Accepted: April 27, 2017 \\ Online Published: May 15, 2017 \\ doi:10.5539/jel.v6n3p305 \\ URL: http://doi.org/10.5539/jel.v6n3p305
}

\begin{abstract}
Critical Thinking Disposition is known as an important factor that drives a student to use Higher Order Thinking Skills (HOTS) in order to solve engineering drawing problems. Infusing them while teaching the subject may enhance students' disposition and higher order thinking skills. However, no research has been done in critical thinking disposition while teaching engineering drawing. The current study is to evaluate how critical thinking disposition infused in Engineering Drawing affected students' thinking disposition. Quasi-experimental with non-equivalent control group design was conducted on the groups from two different Technical Matriculation College for 8 weeks. Two teaching methods, which are Conventional approach and Infusion Approach, were used while teaching Engineering Drawing for control group and treatment group. Control group with 29 students and treatment group consist of 31 students were selected as samples. Pre-test shows that there is no significant different in critical thinking dispositions between control group and treatment group. However, the result in post-test shows that treatment group was significantly higher in critical thinking dispositions compared to control group.
\end{abstract}

Keywords: conventional approach, Higher Order Thinking Skills, Technical Matriculation College, quasi-experiment

\section{Introduction}

Higher Order Thinking Skills (HOTS) among students have been discussed worldwide and emphasized in the educational systems, particularly in developed countries. Malaysia has also taken initiative to incorporate elements of HOTS as one objective of teaching and learning in each subject at all levels of education in order to nurture students who can manipulate and integrate the acquired knowledge learned to make decisions and solve problems in real-life situations (Maier, 1933; Newmann, 1996). However, the importance of critical thinking dispositions that act as internal motivation, which encourages students to use higher order thinking skills (Facione \& Facione, 1992; Tishman \& Andrade, 1996; Facione, Facione, \& Giancarlo, 1997) has received less attention.

In Malaysia, research findings reveal that most teachers choose the rote learning approach for teaching facts and drills due to the exam-oriented education system that exists currently (Ali \& Noordin, 2010; Hong et al., 2011). Such a teaching approach not only hinders the development of higher-order thinking but also promotes negative thinking dispositions such as indifference, bias and negligence in students. In most engineering subjects, the study of engineering drawings is facing a lack of engagement with HOTS. Instead of internalizing concepts, engineering drawing teachers use the drill approach for students to master drawing techniques and prepare them for exam questions (Ali \& Noordin, 2010; Hong et al., 2011). These are the findings of existing studies on teaching but these studies are focused on the needs of teachers.

The existing studies related to engineering drawing have focused on teaching methods and aids. Teaching methods and aids help students understand difficult topics such as tangent, ellipse and parabola easily and to consequently master the drawing technique (Shariffudin, Foong, \& Othman, 2006; Marian, Rahim, Baser, \& Tahar, 2011; Ishar, 2011; Mat Yasin, Halim, \& Ishar, 2012). Teachers believe that these approaches are important for students to solve engineering drawing problems and this belief makes them overlooked the 
importance of HOTS. In fact, HOTS and positive thinking dispositions help students synthesize all the knowledge they have acquired in order to solve problems (Maier, 1933; Newman, 1990).

Scholars have stated that thinking disposition must be developed along with thinking skills, since it encourages students to use the acquired HOTS to solve problems or make decisions (Newman, 1987; Ennis, 1991; Tishman \& Andrade, 1996; Facione, Facione, \& Giancarlo, 1997; Bailin, Case, Coombs, \& Daniels, 1999; Facione, 2000). However, thinking disposition can become negative or positive depending on the learning environment of the students. Learning environments involving higher order thinking activities motivate students to carry out the thinking process of analyzing and interpreting information, identifying causes and consequences, and considering problems and their solutions (Marin \& Halpern, 2011). When students engage in higher-order thinking, they use different types of positive critical thinking dispositions such as open mindedness, inquisitiveness, systematicity, analyticity, truth-seeking, critical thinking self-confidence, and maturity when making judgments (Facione, 2000).

A variety of techniques can be used to guide HOTS and thinking dispositions such as posing deep questions, discussions, dialog, or reflection (Gul, Cassum, Ahmad, Khan, Saeed, \& Parpio, 2010; Thompson, 2011; Ulku, 2012; Siti Rahayah et al., 2012). Higher-order thinking is hindered if the learning environment is only filled with activities such as answering drill questions and memorizing facts. The students not only practice lower-order thinking but also negative thinking dispositions such as negligence, indifference and bias. Accordingly, the teaching and learning of engineering drawings need to be replete with assignments that can challenge students' thinking such as making decisions and solving problems, as it is an important factor that can enhance their problem solving skills and positive-thinking dispositions. Therefore, this study aims to identify an efficient method to inculcate critical thinking dispositions in the context of engineering drawings.

\section{Methodology}

The methodology involved identified the differences in critical thinking disposition between the control group and treatment group. The instrument used to measure dispositions is Malaysia Critical Thinking Instrument (MACTI). MACTI developed by local researcher (Akbariah Mahdzir, 2008) where validity and reliability test has been carried out. Since no changes made to the instrument for this research purposes and it has been used in past study (Siti Nazleen Abdul Rabu, Baharudin Aris, \& Zaidatun Tasir, 2013), no validity and reliability test was carried. Quasi-experimental research with non-equivalent control group design was used in this study. The population consisted of all the students of the Technical Matriculation College, Malaysia located in Kedah, Pahang and Johor. This college was selected because the students who enroll in this college have prior knowledge of Engineering Drawing acquired in their high school. Each college consists of seven to eight classes and each class consists of 30 to 40 students. Two study groups were selected from two colleges that namely the control group and treatment group. These two groups were selected as a sample through purposive sampling technique based on the similarities in the lecturers' knowledge and teaching experiences in Engineering Drawing. Experiments were conducted during the engineering drawing class for two hours a week for eight weeks and the same topics were covered in both the study groups are same. HOTS infused in the topics of engineering drawing are presented in Table 1.

Table 1. Higher-Order Thinking Skills (HOTS) infused in engineering drawing topics

\begin{tabular}{llll}
\hline Week/Topic & $\begin{array}{l}\text { HOTS infused in the } \\
\text { Introduction section } \\
(10 \mathrm{~min})\end{array}$ & $\begin{array}{l}\text { HOTS infused in the Main } \\
\text { section } \\
(1 \mathrm{hr} 45 \mathrm{~min})\end{array}$ & $\begin{array}{l}\text { HOTS infused in the } \\
\text { Closing section } \\
(5 \mathrm{~min})\end{array}$ \\
\hline 1 (Section view) & Analytical and logic & Analytical and logic & Analytical and logic \\
2 (Section view) & Analytical and logic & Analytical and logic & Analytical and logic \\
3 (Section view) & Reasoning & Reasoning & Reasoning \\
4 (Building drawing) & Reasoning & Reasoning & Reasoning \\
5 (Building drawing) & Identifying/Making assumption & Identifying/Making assumption & Identifying/Making \\
& & & assumption \\
6 (Electrical \& Electronic & Identifying/Making assumption & Identifying/Making assumption & Identifying/Making \\
drawing) & & & assumption \\
7 (Electrical \& Electronic & Analytical and logic & Analytical and logic & Analytical and logic \\
\hline
\end{tabular}




\begin{tabular}{lll}
\hline drawing) & & \\
8 (Electrical \& Electronic & Reasoning & Reasoning \\
drawing) & & Reasoning \\
\hline
\end{tabular}

Table 1 reveals that three engineering drawing topics were covered in teaching engineering drawing; section view, building drawing and electrical and electronic drawing. The section view was covered in three weeks, building drawing in two weeks and electrical and electronics is in three weeks. The same system was used for all Technical Matriculation Colleges since their syllabus is the same. Specific HOTS are infused into each topic through assignment that contain problems related to the applications of Engineering Drawing based in real-world scenarios. Specific HOTS infused into particular topics are presented in Table 1 and were only used for the treatment group. The control group was taught the same topics using conventional method that used the drill approach. Before the experiment commenced, the teacher who taught the treatment group received training to ensure that the intervention would go smoothly and with as few mistakes as possible. The training process is presented in Table 2.

Pre-test was conducted using the MACTI for the control and treatment groups before the experiment began. The treatment group was asked to complete drawings in the eight weeks of intervention period. The flow process of intervention for the treatment group is shown in Figure 1. After the intervention was completed, post-test was conducted for both study groups using the same instrument as the pre-test. The data collected from the pre-test and post-test were then analyzed using SPSS and the results were compared.

Table 2. Training timetable for treatment group teacher

\begin{tabular}{|c|c|c|}
\hline DAY/DATE & TIME & ACTIVITY \\
\hline $\begin{array}{l}1 \\
(15 / 08 / 2016)\end{array}$ & $-4.00 \mathrm{pm}$ & $\begin{array}{l}\text { 1. } \text { INTRODUCTION } \\
\text { - } \quad \text { Introduction to the intervention program. } \\
\text { - } \\
\text { Briefing on the intervention objectives. } \\
\text { 2. } \\
\text { INFUSEDEING ON THE HIGHER ORDER THINKING SKILLS (HOTS) TO BE } \\
\text { - } \\
\text { - } \\
\text { Definition of each HOT. }\end{array}$ \\
\hline $\begin{array}{l}2 \\
(16 / 08 / 2016)\end{array}$ & $9.00 \mathrm{am}-4.00 \mathrm{pm}$ & $\begin{array}{l}\text { 1. } \quad \text { EXPLAINING IN DETAIL ABOUT THE STEPS OF TEACHING } \\
\text { HIGHER-ORDER THINKING SKILLS THROUGH ENGINEERING DRAWING } \\
\text { - } \quad \text { HOTS teaching steps based on teaching plan prepared by researcher. } \\
\text { - } \quad \text { Briefing on problem-based learning. } \\
\text { - } \quad \text { Briefing on Infusion Approach. } \\
\text { - } \quad \text { Briefing on teacher's role as a facilitator during intervention. }\end{array}$ \\
\hline $\begin{array}{l}3 \\
(17 / 08 / 2016)\end{array}$ & $9.00 \mathrm{am}-12.00 \mathrm{pm}$ & $\begin{array}{l}\text { - HANDS-ON WORKSHOP WITH RESEARCHER } \\
\text { - The teacher receives an intervention-teaching plan. } \\
\text { - Teacher carries out practical teaching based on intervention-teaching plan with the } \\
\text { researcher. } \\
\text { - Assessment of teacher's understanding on how HOTS are infused during teaching } \\
\text { engineering drawing and the smoothness of the teaching process by the researcher through } \\
\text { observation during practical. }\end{array}$ \\
\hline
\end{tabular}




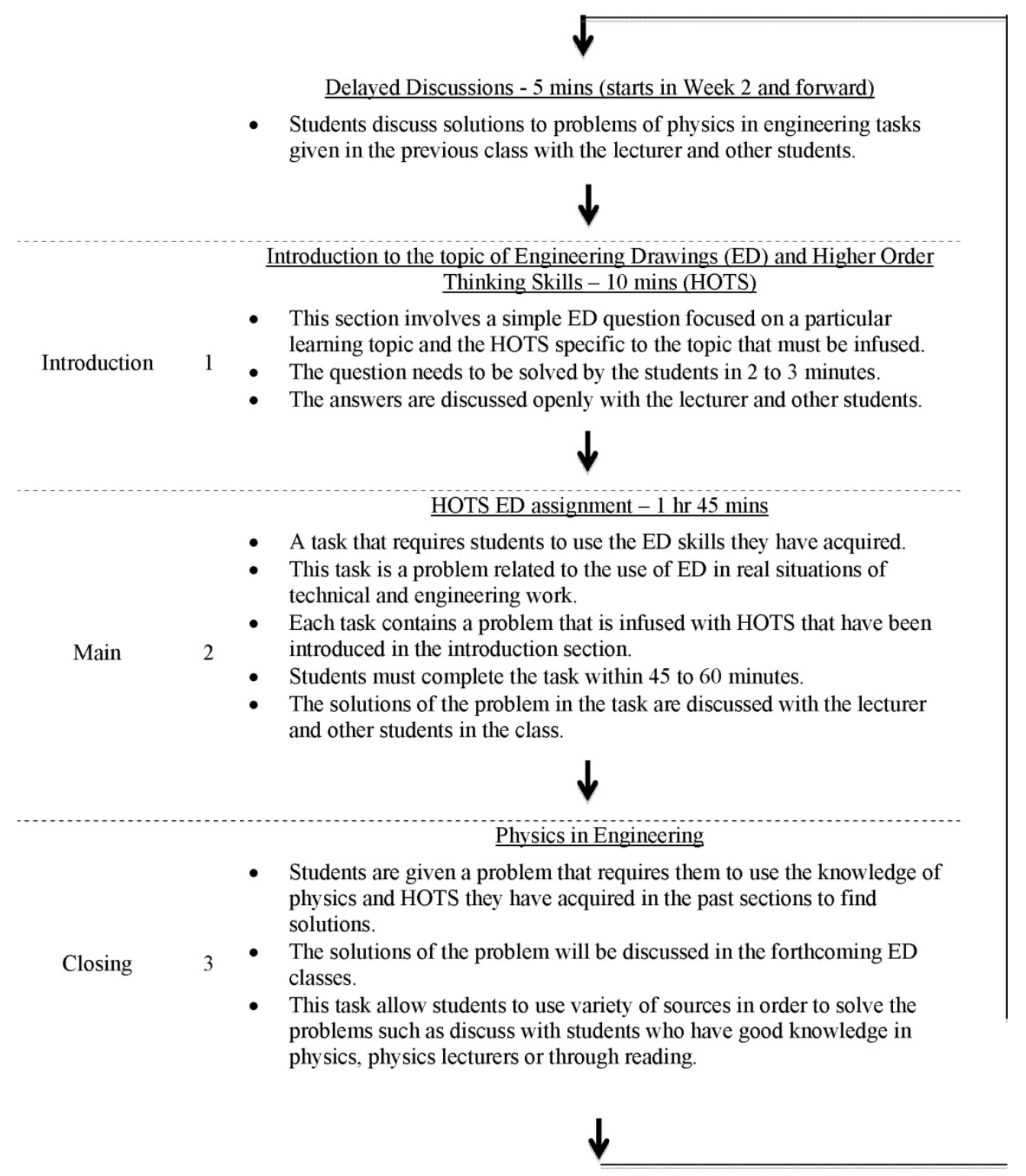

Figure 1. Intervention flow process for treatment group

\section{Results}

The data were analyzed using SPSS and the results were used to identify the differences in the Critical Thinking Dispositions between the control and treatment group. Table 3 contains descriptive statistics based on the overall score in the pre-test and post-test.

Table 3. Critical Thinking Disposition mean score for control group and treatment group

\begin{tabular}{lllll}
\hline & Pre-test & & Post-test & SD \\
\cline { 2 - 5 } & $\mathrm{M}$ & $\mathrm{SD}$ & $\mathrm{M}$ & 2.61 \\
\hline Control group & 51.66 & 3.05 & 50.80 & 1.94 \\
Treatment group & 51.77 & 2.65 & 52.36 & \\
\hline
\end{tabular}


Table 3 shows a decrease in the mean value (51.66 to 50.80) for the control group. The mean score for the treatment group increased in the post-test to 52.36 from 51.77 in the pre-test.

One-way ANOVA was used to study the differences in Critical Thinking Dispositions between the two groups. This analysis was conducted to explore the effects of the teaching method on Critical Thinking Dispositions. The pre-test and post-test results are presented in Tables 4 and 5 .

Table 4. Differences in Critical Thinking Disposition between control group and treatment group on pre-test

\begin{tabular}{llllll}
\hline & $\mathrm{M}$ & $\mathrm{SD}$ & $F$ & $d f$ & $p$ \\
\hline Control group pre-test & 51.66 & 3.05 & .024 & 1,58 & .878 \\
Treatment group pre-test & 51.77 & 2.65 & & & \\
\hline
\end{tabular}

The results of the analysis revealed that there were no significant differences $(p>.05)$ in Critical Thinking Dispositions between the groups on the pre-test: $F(1,58)=.024, p=.878$. Effect size calculated using eta is as follows:

$$
\text { Eta squared }=\frac{.196}{476.069}=.0004
$$

Table 5. Differences in Critical Thinking Disposition between control group and treatment group on post-test

\begin{tabular}{llllll}
\hline & M & SD & $F$ & $d f$ & $p$ \\
\hline Control group post-test & 50.80 & 2.61 & 6.79 & 1,58 & .012 \\
Treatment group post-test & 52.36 & 1.94 & & & \\
\hline
\end{tabular}

The results from the analysis revealed that there was a significant difference $(\mathrm{p}<.05)$ in Critical Thinking Disposition between the two groups on the post-test: $F(1,58)=6.79, p=.012$. Effect size calculated using eta squared is as follows:

$$
\text { Eta squared }=\frac{36.238}{345.990}=.105
$$

\section{Discussion}

These findings suggest that the conventional teaching approach, which is an exam-oriented teaching method, prevented the development of a positive critical thinking disposition among students in the control group. This method only encouraged students to memorize facts and become familiar with exam questions and their conventional solutions. Therefore, the students were not motivated to practice positive critical thinking dispositions as the learning environment did not require them to think critically.

The infusion approach teaching method to which the treatment group was exposed was supported by problem-solving strategies and techniques such as questioning and discussion, and created a learning environment that encouraged students to be actively involved in higher-order thinking. Students' thinking is always challenged by higher order thinking problems that require them to find alternative solutions systematically, analyze the problems and their solutions critically, become confident while reasoning, remain open-minded when being criticized by others and make mature judgment by taking into account others' views as well as their own decisions.

As an example, the students received a section view question that needs them to suggest type of section views that able to exposed as much important details to ease production. Then the students present it in front of other students and lecturer in the class. Through presentation they were encouraged to reason the judgment made when selecting a particular section view. They also provoked with questions that need them to defend their idea by synthesizing knowledge and experienced learned. Such behaviors that were practiced regularly through the eight 
weeks of intervention helped in developing a positive critical thinking disposition among students in the treatment group.

\section{Conclusion}

This study reveals that the treatment group has slightly improved positively in terms of critical thinking dispositions. Even though the improvement is small owing to the fact that they practiced critical thinking dispositions only during the Engineering drawing class that is held only for two hours a week, an improvement in thinking dispositions compared to the control group was nevertheless observed. The students in the control group who were taught engineering drawing using the drill approach for eight weeks of the class exhibited negative thinking dispositions such as indifference, intolerance, close-mindedness and disinclination towards reasoning. Regarding the treatment group, the real-world problems posted in their assignments, questions and answers session, and discussions encouraged them to use higher order thinking and to practice positive thinking dispositions. Feedback from other students and the lecturer encouraged the student who presenting their work to defend their ideas, argued with confidence and practiced open-mindedness when evaluating and comparing their stand with others. Therefore, we can conclude that the infusion approach supported by problem solving as a strategy and techniques such as questioning and discussion did contribute to the development of critical thinking disposition.

\section{References}

Azaman Ishar. (2012). Kesan Inovasi MTEP LK Dalam Pengajaran dan Pembelajaran Lukisan Kejuruteraan Dalam Kalangan Pelajar Tingkatan Empat di Sekolah Menengah Teknik (Tesis PhD). Universiti Kebangsaan Malaysia.

Fred, M. N. (1990). Higher order thinking in teaching social studies: A rationale for the assessment of classroom thoughtfulness. Journal of Curriculum Studies, 22(1), 41-56. https://doi.org/10.1080/0022027900220103

Lisa, M. M., \& Diane, F. H. (2011). Pedagogy for developing critical thinking in adolescents: Explicit instruction produces greatest gains. Thinking Skills and Creativity, 6(2011), 1-13. https://doi.org/10.1016/j.tsc.2010.08.002

Marlina, A., \& Shaharom, N. (2010). Hubungan Antara Kemahiran Berfikir Kritis Dengan Pencapaian Akademik Dalam Kalangan Pelajar Fakulti Pendidikan Universiti Teknologi Malaysia. Jurnal Teknologi (Sains Sosial), 52, 44-55.

Mohd, F. M., Mohd, B. R., Jamil, A. B., \& Mohd, S. T. (2011). Keberkesanan Penggunaan CD Interaktif Lukisan Isometrik Terhadap Kemahiran Visualisasi Pelajar. Persidangan Kebangsaan Penyelidikan dan Inovasi Pendidikan dan Latihan Teknik dan Vokasional.

Nagappan, R. (2001). The Teaching of Higher-Order Thinking Skills in Malaysia. Journal of Southeast Asian Education, 2(1).

Noreen, C. F., \& Peter, A. F. (1992). The California Critical Thinking Disposition Inventory test manual. Milbrae, CA: California Academic Press.

Norman, R. F. M. (1933). An aspect of human reasoning. British Journal of Psychology, 24, 144-155.

OECD. (2014). PISA 2012 Results in Focus: What 15-year-olds know and what they can do with what they know. Retrieved from http://www.oecd.org/pisa/keyfindings/pisa-2012-results-overview.pdf

Peter, A. F. (2000). The Disposition Toward Critical Thinking: Its Character, Measurement, and Relationship to Critical Thinking Skill. Informal Logic, 20(1), 61-84.

Peter, A. F., Noreen, C. F., \& Carol, A. F. G. (1997). Professional Judgement and the Disposition Toward Critical Thinking. Milbrae, CA: California Academic Press.

Raisa, G., Shanaz, C., Azra, A., Shehla, K., Tanveer, S., \& Yasmin, P. (2010). Enhancement of critical thinking in curriculum design and delivery: A randomized controlled trial for educators. Procedia Social and Behavioral Science, 2(2010), 3218-3225.

Rio, S. S., Lee, M. F., \& Widad, O. (2006). E-ENGINEERING DRAWING (EEDTM)—A WEB BASED SYSTEM FOR TEACHING AND LEARNING ENGINEERING DRAWING FOR UPPER SECONDARY SCHOOLS.

Robert, E. (1991). Critical Thinking: A Streamlined Conception. Teaching Philosophy, 14(1). Retrieved from http://www.criticalthinking.net/EnnisStreamConc1991\%20LowRes.pdf 
Robert, H. E. (1993). Critical Thinking Assessment. Theory into Practice, 32(3), 179-186. https://doi.org/10.1080/00405849309543594

Robert, S., \& Rebecca, R. (1998). Infusing Critical and Creative Thinking into Content Instruction. Staff Development Manual, The National Center for Teaching Thinking. Retrieved from https://repository.nie.edu.sg/bitstream/10497/3681/8/SCTT1-5a.pdf

Ruhizan, M., Yasin, L. H., \& Azaman, I. (2012). Effects of Problem-solving Strategies in the Teaching and Learning of Engineering Drawing Subject. Asian Social Science, 8(16), 65-79.

Shari, T., \& Albert, A. (1996). Thinking dispositions: A review of current theories, practices, and issues. Cambridge, Harvard University.

Sharifah, N. P., Nor, A. G., Mohd, M. T., \& Aliza, A. (2012). Keprihatinan Guru Bahasa Melayu dalam melaksanakan kemahiran berfikir secara kritis dan kreatif. Jurnal Pendidikan Bahasa Melayu, Malay Language Education (MyLej), 2(2), 19-23.

Sharon, B., Roland, C., Jerrold, R. C., \& Leroi, B. D. (1999). Conceptualizing Critical Thinking. Journal of Curriculum Studies, 31(3), 285-302. https://doi.org/10.1080/002202799183133

Siti Rahayah, A. et al. (2008). Kemahiran Pemikiran Kritikal dan Penyelesaian Masalah Pelajar-pelajar Sains di Malaysia. Bangi: Fakulti Pendidikan UKM.

Ulku, S. K. (2012). How to Teach Critical-thinking in social studies education: An Examination of Three NCSS Journals. Eurasian Journal of Educational Research, 49, 197-212.

Yahya, B., \& Norhusna, M. (2010). Aplikasi Pemikiran Kreatif dan Kritis Dalam Pengajaran Guru-guru Teknikal Bagi Mata Pelajaran Teknikal di Sekolah Menengah Teknik di Negeri Johor. Universiti Teknologi Malaysia.

Yee, M. H., Widad, O., Jailani, M. Y., Tee, T. K., Razali, H., \& Mimi, M. M. (2011). The Level of Marzano Higher Order Thinking Skills among Technical Education Students. International Journal of Science and Humanity, 1(2), 121-126.

\section{Copyrights}

Copyright for this article is retained by the author(s), with first publication rights granted to the journal.

This is an open-access article distributed under the terms and conditions of the Creative Commons Attribution license (http://creativecommons.org/licenses/by/4.0/). 